ERRATA

Genes \& Development 32: 1344-1357 (2018)

Erratum: Single-nucleus transcriptomic survey of cell diversity and functional maturation in postnatal mammalian hearts

Peng Hu, Jian Liu, Juanjuan Zhao, Benjamin J. Wilkins, Katherine Lupino, Hao Wu, and Liming Pei

Supplemental Tables S1-S9 were inadvertently excluded from the initial publication of this article and can now be found in the Additional Supplemental Material link online.

doi: $10.1101 / \operatorname{gad} .332692 .119$

Genes \& Development 33: 828-843 (2019)

\title{
Erratum: Dedifferentiation by adenovirus E1A due to inactivation of Hippo pathway effectors YAP and TAZ
}

Nathan R. Zemke, Dawei Gou, and Arnold J. Berk

Supplemental Table S1 was inadvertently excluded from the initial publication of this article and can now be found in the Additional Supplemental Material link online.

doi: $10.1101 / \operatorname{gad} .332684 .119$ 


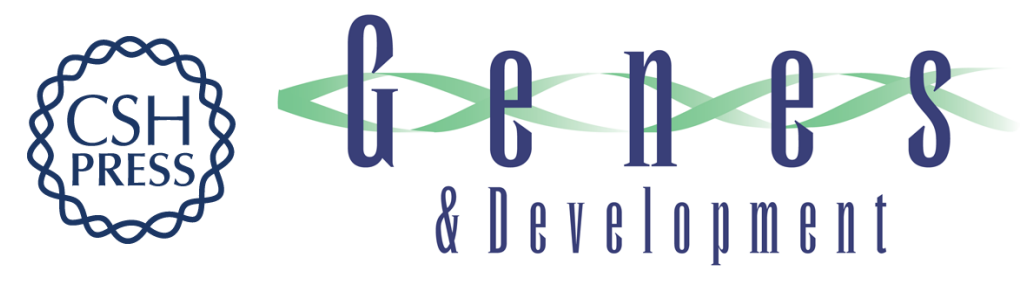

\section{Erratum: Single-nucleus transcriptomic survey of cell diversity and functional maturation in postnatal mammalian hearts}

Peng $\mathrm{Hu}$, Jian Liu, Juanjuan Zhao, et al.

Genes Dev. 2019, 33:

Access the most recent version at doi:10.1101/gad.332692.119
Related Content Single-nucleus transcriptomic survey of cell diversity and functional maturation in postnatal mammalian hearts
Peng Hu, Jian Liu, Juanjuan Zhao, et al.
Genes Dev. October , 2018 32: 1344-1357
License
Email Alerting Receive free email alerts when new articles cite this article - sign up in the box at the top
Service right corner of the article or click here.

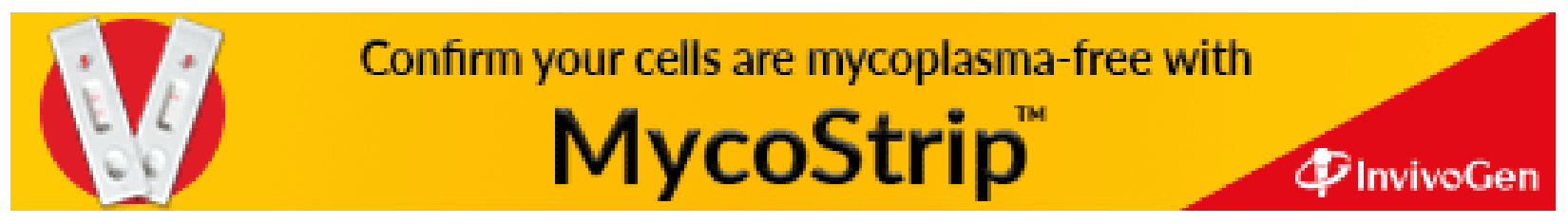

